\title{
Haematological, organs and performance response of cockerel chicks fed urea-treated and fermented brewer's dried grains diets as replacement for groundnut cake
}

\author{
Isikwenu, J.O \\ Department of Animal Science, Delta State University, Asaba Campus, Delta State, Nigeria. \\ Email: jisikwenu@Yahoo.Com
}

\begin{abstract}
The effect of replacing groundnut cake with urea-treated and fermented brewer's dried grains at $0,25,50,75$ and $100 \%$ graded levels in cockerel chicks at $0-8$ weeks of age was investigated. Five diets were formulated to be isonitrogenous and isocaloric to provide $20 \%$ crude protein and $2684.06 \mathrm{Kcal} / \mathrm{kg}$ metabolizable energy. Three hundred day old cockerel chicks (Isa Brown breed) were randomly allocated to five treatment groups replicated thrice with 20 cockerel chicks per replicate, fed and watered ad libitum in deep litter pens for 8 weeks. There were significant $(P>$ 0.05 ) differences in mean body weights, daily weight gain, feed intake, feed conversion ratio, haematological indices and organ weights of cockerel chicks fed the control and urea-treated and fermented BDG diets. Cockerel chicks fed the control diet were significant $(P>0.05)$ better in weight performance. Organs weight response were similar to body weight gain pattern.
\end{abstract}

Keywords: Urea-treated, Brewer's dried gains, Groundnut cake, Cockerel chicks.

\section{INTRODUCTION}

Feed cost is always the largest item of expenditure in poultry production and protein sources are the most expensive among the ingredients used for feeds. The need to intensively explore the use of agricultural and agro-based industrial by-products as replacers, substitutes and complements for the more expensive conventional protein sources have been advocated, and brewer's dried grains (BDG) is one of such byproducts (Isikwenu, 2006). BDG is cheap, readily available, not directly required by man and according to Aduku (1993) supply the same quality protein as groundnut cake (GNC) because they have similar amino acid profile. The major obstacle to the use of large quantity of BDG as a source of plant protein is it's high fibre content. Alkali treatment of various fibrous materials have been used to improve their nutritional qualities (Faniyi et al.,1997; Vipond et al., 2001 and Isikwenu, 2006). Further processing of $\mathrm{BDG}$ in order to reduce it's fibre content was carried out by the use of urea-treatment and fermentation. Urea-treated and fermented BDG have been successfully used in broiler starter diets as a replacement for GNC up to $16.70 \%$ of the diet without adverse effects (Isikwenu et al., 2008). This study is, therefore, designed to investigate the effect of replacing GNC with urea - treated and fermented $B D G$ in cockerel chicks diets.

\section{MATERIALS AND METHODS}

Experimental Site: This experiment was carried out at the Poultry Research Unit of the Department of Animal Science, Delta State University, Asaba Campus, with a mean annual rainfall, temperature and relative humidity of $1137 \mathrm{~mm}, 32.7^{\circ} \mathrm{C}$ and $82 \%$ respectively. It lies on latitude $5^{0} 30^{1}$ and $5^{0} 45^{1} \mathrm{~N}$ of the equator and longitude $5^{\circ} 40^{1}$ and $6^{\circ} \mathrm{E}$ of the Greenwich Meridian.

Experimental Birds and Management: A total of three hundred (300) day old cockerel chicks (Isa Brown Breed) were used in this investigation. The birds were managed in a deep litter house of fifteen pens with dimensions of $2.04 \mathrm{~m} \times 2.03 \mathrm{~m}$ for the eight weeks duration of the experiment. Feed and water were provided ad libitum while necessary prophylaxis and vaccination were administered.

Experimental Design: The cockerel chicks were allotted into five treatment groups with three replicates on equal weight basis in a completely randomized design. Each treatment group consists of 60 cockerel chicks and 20 in each replicate.

Experimental Diets: Urea - treated and fermented brewer's dried grains (BDG) was used to replace groundnut cake (GNC) at 0, 25, 50, 75 and 100\% levels in cockerel chicks diets on protein equivalent basis. The BDG used in this study was treated and fermented for 7 days using $2 \%$ urea concentration ( $20 \mathrm{~g}$ urea per litre of water, using $46 \% \mathrm{~N}$, fertilizer 
grade urea, Isikwenu et al., 2007). Five treatment diets were formulated to be isonitrogenous and isocaloric to provide $20 \%$ crude protein and
$2684.06 \mathrm{Kcal} / \mathrm{kg}$ metabolizable energy. The composition of the cockerel chicks diets and their proximate compositions are presented in Table 1.

Table 1: Composition of Experimental Cockerel Chicks Diets (0 - 8weeks)

\begin{tabular}{|c|c|c|c|c|c|}
\hline \multicolumn{6}{|c|}{ Dietarv Treatments } \\
\hline $\begin{array}{ll}\text { Replacement level } \\
(\%)\end{array}$ & $\begin{array}{l}100 \text { GNC } \\
00 \text { UTBDG }\end{array}$ & $\begin{array}{l}75 \text { GNC } \\
25 \text { UTBDG }\end{array}$ & $\begin{array}{l}50 \text { GNC } \\
50 \text { UTBDG }\end{array}$ & $\begin{array}{l}25 \text { GNC } \\
75 \text { UTBDG }\end{array}$ & $\begin{array}{l}00 \text { GNC } \\
100 \text { UTBDG }\end{array}$ \\
\hline \multicolumn{6}{|l|}{ Ingredients } \\
\hline Maize (yellow) & 52.70 & 51.78 & 50.45 & 49.30 & 48.00 \\
\hline Groundnut cake & 21.50 & 16.12 & 10.75 & 5.38 & - \\
\hline Urea Treated BDG & - & 6.30 & 13.00 & 19.52 & 26.20 \\
\hline Wheat Offal & 15.00 & 15.00 & 15.00 & 15.00 & 15.00 \\
\hline Fish meal & 5.00 & 5.00 & 5.00 & 5.00 & 5.00 \\
\hline Bone meal & 3.20 & 3.20 & 3.20 & 3.20 & 3.20 \\
\hline Limestone & 1.40 & 1.40 & 1.40 & 1.40 & 1.40 \\
\hline Salt & 0.50 & 0.50 & 0.50 & 0.50 & 0.50 \\
\hline Methionine & 0.20 & 0.20 & 0.20 & 0.20 & 0.20 \\
\hline Premix * & 0.50 & 0.50 & 0.50 & 0.50 & 0.50 \\
\hline Total & 100.00 & 100.00 & 100.00 & 100.00 & 100.00 \\
\hline \multicolumn{6}{|l|}{$\begin{array}{l}\text { Calculated } \\
\text { Analysis: }\end{array}$} \\
\hline Crude Protein (\%) & 20.01 & 20.01 & 19.98 & 19.97 & 20.00 \\
\hline Crude Fibre (\%) & 5.85 & 6.15 & 6.50 & 6.83 & 7.17 \\
\hline $\begin{array}{l}\text { Metabolizable Energy } \\
\text { (Kcal/kg) }\end{array}$ & 2684.06 & 2674.71 & 2661.60 & 2650.14 & 2637.31 \\
\hline \multicolumn{6}{|l|}{$\begin{array}{l}\text { Determined } \\
\text { Analysis: }\end{array}$} \\
\hline Dry Matter (\%) & 90.64 & 90.67 & 91.00 & 90.00 & 92.55 \\
\hline Crude Fibre (\%) & 10.00 & 11.00 & 14.00 & 15.00 & 17.00 \\
\hline Ether Extract & 8.01 & 9.03 & 10.06 & 11.11 & 13.74 \\
\hline Crude Protein & 20.34 & 20.25 & 20.18 & 20.16 & 20.13 \\
\hline Ash (\%) & 4.50 & 5.20 & 7.20 & 8.40 & 10.90 \\
\hline NFE & 47.79 & 45.19 & 3936 & 35.33 & 30.78 \\
\hline
\end{tabular}

* Each $2.5 \mathrm{~kg}$ vitamin-mineral premix provided the following:

A 12,000,000 IU; $D_{3}$ 2,500,000 IU; E 30,000 IU; K 2,500mg; B 2,000mg; B12 40,000mg; Niacin 15,000mg; Pantothenic acid 1,500mg; Folic acid 50mg; Biotin 30,000mg; Chlorin 80,000mg; Manganese 50,000mg; Zinc 20,000mg; Copper $1,000 \mathrm{mg}$; lodine 200mg; Selenium 500mg; Cobalt 200mg.

GNC: Groundnut cake, UTBDG: Urea-treated and fermented Brewer's Dried Grains 
Measurements: Data on weight changes, feed intake and mortality were recorded on replicate basis weekly, while feed conversion ratio was obtained according to Lambert et al. (1936). Blood samples approximately $10 \mathrm{ml}$ per bird were collected from replicates in each treatment group by severing the jugular vein in the neck during slaughtering, into specimen bottles with ethylene diamine tetra-acetic acid (EDTA) at the end of the experiment. Haematological parameters such as packed cell volume (PCV) was determined by Wintrobe's microhaematocrit method, red blood cell count (RBC) and white blood cell count (WBC) were by Neubauer haemocytometer and haemoglobin concentration $(\mathrm{Hb})$ by Cyanomethaemoglobin method. The mean corpuscular volume (MCV), mean corpuscular haemoglobin $(\mathrm{MCH})$ and mean cell haemoglobin concentration (MCHC) were computed as outlined by Seal and Erickson (1979).

Chemical Analysis: The chemical analysis of the proximate compositions of the experimental diets (Table 1) and test ingredients (Table 2 and Table 3 ) were carried out according to the procedure of A.O.A.C (1990).

Table 2: Proximate Analysis of Urea-Treated and Fermented BDG and Untreated BDG

\begin{tabular}{|l|c|c|}
\hline \multicolumn{1}{|c|}{ Parameters \% } & Urea - Treated BDG & Untreated BDG \\
\hline Dry matter & 88.76 & 93.34 \\
\hline Crude Protein & 38.52 & 24.21 \\
\hline Crude fibre & 4.49 & 11.20 \\
\hline Ether extract & 4.87 & 3.69 \\
\hline Ash & 5.99 & 8.04 \\
\hline Nitrigen free extract & 34.89 & 46.20 \\
\hline Organic matter & 82.77 & 85.30 \\
\hline Gross Energy Kcalg ${ }^{1}$ (calculated) & 5.17 & 5.14 \\
\hline
\end{tabular}

Source: Isikwenu et al. (2007)

Table 3: Chemical Composition of Groundnut Cake and Brewer's-Dried Grains

\begin{tabular}{|l|c|c|}
\hline \multicolumn{1}{|c|}{ Chemical components } & GNC & BDG (Untreated) \\
\hline Crude Protein & 45.00 & 27.90 \\
\hline Ether extract & 9.16 & 7.40 \\
\hline Crude fibre & 3.81 & 11.70 \\
\hline Ash & 5.51 & 4.80 \\
\hline Calcium & 0.20 & 0.30 \\
\hline Phosphorus & 0.60 & 0.88 \\
\hline TDN & 76.00 & 78.00 \\
\hline ME Kcal/kg (Swine) & 3185.00 & 2240.00 \\
\hline ME Kcal/kg (Poultry) & 2530.00 & 2513.00 \\
\hline Lysine & 1.73 & 0.90 \\
\hline Methionine & 0.44 & 0.60 \\
\hline Cystein & 0.72 & 0.40 \\
\hline Arginine & 5.00 & 1.30 \\
\hline Tryptophan & 0.49 & 0.40 \\
\hline
\end{tabular}

Source: Aduku (1993)

Statistical Analysis: Data obtained were subjected to analysis of variance and treatment means were compared by Duncan's multiple range test (Duncan, 1955) using SPSS 10.0 package. 


\section{RESULTS}

The effect of urea-treated and fermented BDG inclusion levels on the body weight performance in cockerel chicks is presented in Table 4. The final mean body weight, daily weight gain and feed intake of cockerel chicks fed the control diet were significantly $(P<0.05)$ higher than those fed ureatreated and fermented BDG diets. The feed conversion ratio of cockerel chicks fed the control and $25 \%$ inclusion level of urea-treated and fermented BDG diets were similar $(P>0.05)$ but significantly $(P<0.05)$ better than those fed 50,75 and $100 \%$ inclusion levels of urea-treated and fermented BDG diets. Mortality was low and evenly spread, ranging from 0.80 to $1.00 \%$. The results of the haematological indices are presented in Table 5. There were no significant $(P>0.05)$ differences among cockerel chicks fed the experimental diets in packed cell volume (PCV), haemoglobin ( $\mathrm{Hb})$ content, red blood cell count (RBC), mean corpuscular haemoglobin $(\mathrm{MCH})$ and mean cell haemoglobin concentration $(\mathrm{MCHC})$ values. Significant $(P<0.05)$ differences were observed in the white blood cell count (WBC) and mean corpuscular volume (MCV) values. The WBC of cockerel chicks fed urea-treated and fermented BDG diet of $25 \%$ inclusion level were significantly $(P>$
0.05) higher than the control and other treatment groups, however, the control diet was higher $(\mathrm{P}<$ 0.05 ) than those with inclusion levels of 50,75 and $100 \%$ urea-treated and fermented BDG. The MCV values of cockerel chicks fed 25,75 , and $100 \%$ Ureatreated and fermented BDG diets were similar $(P>$ $0.05)$ but were significantly $(P<0.05)$ higher than those of the control diet and $50 \%$ inclusion level. The results of the organ weights of cockerel chicks fed the experimental diets are presented in Table 6. The liver and spleen weights of cockerel chicks fed the $25 \%$ urea-treated and fermented BDG diet were significantly $(P<0.05)$ heavier than all other treatment groups. However, the spleen weights of the control and 50 inclusion level were similar $(P>0.05)$ while the liver weight of the cockerel chicks fed the control were higher $(P<0.05)$ than the other treatment groups. The heart weight of cockerel chicks fed the control diet were similar $(P>0.05)$ to the $25 \%$ urea-treated and fermented BDG diet but significantly $(P<0.05)$ higher than those cockerel chicks fed the other diets. The gizzard weight of the cockerel chicks fed the control diet and 25\% ureatreated and fermented BDG inclusion level were similar $(P>0.05)$ but were significantly $(P<0.05)$ heavier than the gizzard weight of the other diets.

Table 4: Performance Characteristics of Cockerel Chicks Fed Experimental Diets (0 - 8weeks)

\begin{tabular}{|c|c|c|c|c|c|c|}
\hline $\begin{array}{l}\text { Replacement } \\
\text { Level (\%) }\end{array}$ & $\begin{array}{l}100 \text { GNC } \\
00 \text { UTBDG }\end{array}$ & $\begin{array}{l}75 \text { GNC } \\
25 \text { UTBDG }\end{array}$ & $\begin{array}{l}50 \text { GNC } \\
50 \text { UTBDG }\end{array}$ & $\begin{array}{l}25 \text { GNC } \\
75 \text { UTBDG }\end{array}$ & $\begin{array}{l}00 \text { GNC } \\
100 \text { UTBDG }\end{array}$ & SEM \\
\hline Body weight (g/b) & $564.48^{a}$ & $514.69^{b}$ & $477.78^{c}$ & $431.96^{\mathrm{d}}$ & $448.34^{\mathrm{d}}$ & 13.90 \\
\hline $\begin{array}{l}\text { Daily weight gain } \\
\text { (g/b/d) }\end{array}$ & $60.61^{a}$ & $51.06^{b}$ & $44.71^{\mathrm{C}}$ & $42.61^{d}$ & $43.59^{\text {cd }}$ & 1.85 \\
\hline Feed Intake $(\mathrm{g} / \mathrm{b} / \mathrm{d})$ & $110.69^{\mathrm{a}}$ & $92.62^{b}$ & $94.54^{\mathrm{D}}$ & $96.01^{b}$ & $95.19^{b}$ & 1.95 \\
\hline Feed: Grain Ratio & $1.82^{\mathrm{a}}$ & $1.81^{\mathrm{a}}$ & $2.02^{b}$ & $2.25^{\mathrm{C}}$ & $2.18^{c}$ & 0.49 \\
\hline Mortality (\%) & 0.80 & 1.00 & 0.80 & 0.80 & 1.00 & \\
\hline
\end{tabular}

GNC: Groundnut Cake UTBDG: Urea-treated and fermented brewer's dried grains. SEM: Standard error of the mean. g/b/d: grams/bird/day 
Table 5: Haematological Indices of Cockerel Chicks Fed Experimental Diets ( 0 - 8weeks)

\begin{tabular}{|c|c|c|c|c|c|c|}
\hline $\begin{array}{l}\text { Replacement } \\
\text { Level (\%) }\end{array}$ & $\begin{array}{l}100 \text { GNC } \\
00 \text { UTBDG }\end{array}$ & $\begin{array}{l}75 \text { GNC } \\
25 \text { UTBDG }\end{array}$ & $\begin{array}{l}50 \text { GNC } \\
50 \text { UTBDG }\end{array}$ & $\begin{array}{l}25 \text { GNC } \\
75 \text { UTBDG }\end{array}$ & $\begin{array}{l}00 \text { GNC } \\
100 \text { UTBDG }\end{array}$ & SEM \\
\hline PCV (\%) & $25.67^{a}$ & $26.71^{a}$ & $26.67^{a}$ & $27.00^{a}$ & $26.68^{a}$ & 1.57 \\
\hline $\mathrm{Hb}(\mathrm{g} / \mathrm{dl})$ & $4.30^{\mathrm{a}}$ & $4.57^{\mathrm{a}}$ & $4.63^{\mathrm{a}}$ & $4.53^{\mathrm{a}}$ & $4.51^{a}$ & 0.69 \\
\hline $\operatorname{RBC}\left(10^{6} / \mathrm{mm}^{3}\right)$ & $2.63^{\mathrm{a}}$ & $2.57^{a}$ & $2.75^{a}$ & $2.52^{a}$ & $2.51^{a}$ & 0.35 \\
\hline WBC $\left(10^{6} / \mathrm{mm}^{3}\right)$ & $1.44^{\mathrm{b}}$ & $1.62^{\mathrm{a}}$ & $1.37^{\mathrm{C}}$ & $1.30^{\mathrm{de}}$ & $1.27^{\mathrm{e}}$ & 0.03 \\
\hline $\mathrm{MCH}(\mathrm{pg})$ & $16.35^{a}$ & $17.78^{a}$ & $16.84^{\mathrm{a}}$ & $17.98^{\mathrm{a}}$ & $17.97^{\mathrm{a}}$ & 0.18 \\
\hline MCV (fl) & $97.60^{b}$ & $103.93^{\mathrm{a}}$ & $96.98^{b}$ & $107.14^{\mathrm{a}}$ & $106.29^{a}$ & 1.15 \\
\hline $\mathrm{MCHC}(\%)$ & $16.75^{\mathrm{a}}$ & $17.11^{\mathrm{a}}$ & $17.36^{\mathrm{a}}$ & $16.78^{a}$ & $16.90^{\mathrm{a}}$ & 0.17 \\
\hline
\end{tabular}

GNC: Groundnut Cake UTBDG: Urea-treated and fermented brewer's dried grains. SEM: Standard error of the mean.

Table 6: Organ Weights of Cockerel Chicks Fed Experimental Diets (0 - 8weeks)

\begin{tabular}{|c|c|c|c|c|c|c|}
\hline $\begin{array}{l}\text { Replacement Level } \\
\text { (\%) }\end{array}$ & $\begin{array}{l}100 \text { GNC } \\
00 \text { UTBDG }\end{array}$ & $\begin{array}{l}75 \text { GNC } \\
25 \text { UTBDG }\end{array}$ & $\begin{array}{l}50 \text { GNC } \\
50 \text { UTBDG }\end{array}$ & $\begin{array}{l}25 \text { GNC } \\
75 \text { UTBDG }\end{array}$ & $\begin{array}{l}00 \text { GNC } \\
100 \text { UTBDG }\end{array}$ & SEM \\
\hline Liver (g) & $26.47^{b}$ & $28.23^{a}$ & $15.82^{C}$ & $10.80^{d}$ & $11.44^{\mathrm{d}}$ & 1.99 \\
\hline Heart $(\mathrm{g})$ & $3.64^{\mathrm{a}}$ & $3.37^{\mathrm{ab}}$ & $2.89^{\mathrm{C}}$ & $2.91^{b c}$ & $1.66^{\mathrm{d}}$ & 0.19 \\
\hline Spleen (g) & $0.80^{\mathrm{b}}$ & $1.43^{\mathrm{a}}$ & $0.81^{b}$ & $0.74^{\mathrm{C}}$ & $0.75^{c}$ & 0.07 \\
\hline Gizzard (g) & $23.27^{a}$ & $27.60^{a}$ & $15.38^{b}$ & $16.77^{\mathrm{b}}$ & $15.66^{b}$ & 1.46 \\
\hline
\end{tabular}

GNC: Groundnut Cake. UTBDG: Urea-treated and fermented brewer's dried grains. SEM: Standard error of the mean. $\mathrm{g}: \mathrm{grams}$

\section{DISCUSSION}

The average body weight, daily weight gain and feed intake of cockerel chicks fed the control diet were superior to those fed with urea-treated and fermented BDG diets. These results indicate that the control diet was nutritionally better than those of urea-treated and fermented BDG diets in nutrient content, availability, acceptability and utilization. The feed conversion ratio followed the same pattern as the weight performance and feed intake values except for the diet with $25 \%$ urea-treated and fermented BDG which was similar to the control diet. The feed conversion ratio obtained in this study are consistent with the range of values reported by Isikwenu et al. (2008) for broiler chickens fed similar diets. The decrease in feed intake of urea-treated and fermented BDG diets may be due to poor acceptability and bulkiness of the feed containing high BDG levels compared to groundnut cake (GNC). The observed average body weight and daily weight gains agree with the feed intake pattern of cockerel chicks which means the urea-treated and fermented BDG diets were unable to furnish the cockerel chicks with adequate nutrients for tissue synthesis to achieve a growth rate comparable to the control diet which has GNC. The lower weight performance of cockerel chicks fed urea-treated and fermented BDG diets might have been caused by nutrient intake restriction precipitated by lower feed intake or nutrient dilution effect of non-starch polysaccharides (NSPs) and bulkiness of the feeds. This result is supported by previous reports on the implication of restricted feed intake on growth rate and body weight performance (Fattori et al., 1991; Ubosi, 1998; Mench, 2002; Isikwenu et al., 2008 and Isikwenu, 2011). The similarity in the PCV, Hb, RBC, MCH and $\mathrm{MCHC}$ values shows that urea-treated and fermented BDG diets had no adverse effect on the blood levels, the air exchange or oxygen carrying capacity and caused no anaemic conditions in the birds. The values of $\mathrm{PCV}, \mathrm{Hb}, \mathrm{MCH}$ and $\mathrm{MCHC}$ of this experiment are within the normal range of values and are similar to those reported by Isikwenu et al. (2007) and Ojebiyi et al, (2009) for broiler chicks fed urea-treated and fermented BDG and Kola (Cola acuminata) husk meal respectively. The WBC values of the control was only superior to diets of 50 to $100 \%$ inclusion levels, which indicate that cockerels fed the $25 \%$ inclusion level had better immunity 
status than the control, however, immunity decreased with increasing levels of urea-treated and fermented BDG inclusion. This decrease may not be unconnected with the lower nutrient intake arising from lower voluntary feed intake of the cockerels as the levels of urea-treated and fermented BDG increases in the diets. The MCV values of 25, 75 and $100 \%$ of urea-treated and fermented BDG diets were better than the control diet, and this shows that the urea-treated and fermented BDG in the diets had no detrimental effects on the blood level of the birds. The weight of the organs (liver, heart, spleen and gizzard) generally decreased with increasing inclusion of urea-treated and fermented BDG in the diets. The organs weight response was similar to that of the average body and daily weight gains of cockerels fed the experimental diets. This may be attributed to the nutrient intake restriction caused by low feed intake which resulted in a lower general body weight performance of cockerels fed ureatreated and fermented BDG diets.

\section{CONCLUSION}

The results of the weight performance showed that urea-treated and fermented BDG cannot be used as an alternative plant protein source to groundnut cake in cockerel chicks diets. However the values of the weight performance showed some promise of a likely good weight increase if the crude protein and energy levels are raised in a further investigation. Haematological parameters indicate that the use of urea-treated and fermented BDG has no adverse health implications on the birds. The use of ureatreated and fermented BDG in cockerel chicks diet is safe.

\section{REFERENCE}

Aduku, A.O. (1993). Tropical Feedstuff Analysis Table. Faculty of Agriculture, Department of Animal Science, Ahmadu Bello University, Samaru - Zaria, Nigeria.

AOAC (1990). Official Methods of Analysis. Association of Official Analytical Chemists $15^{\text {th }}$ edition, Washington D.C.

Duncan, D.B. (1955). Multiple Range and Multiple F-tests. Biometrics 11:1 - 42 .

Faniyi G.F., Ologhobo, A.D., Adeniran, G.A and Alaka, O.O. (1997). Chemical characterization of untreated and treated cowpea sorghum seedhulls used as poultry feed ingredients. Pp $41-52$. Ologhobo, A.D. lyayi, E.A., Adesehinwa, A.O. and Bamgbose, A.M., (Eds). In Livestock Products. Proceedings of $2^{\text {nd }}$
Annual Conference of Animal Science Association of Nigeria. September $16^{\text {th }}-19^{\text {th }} 1997$, Ikeja - Lagos.

Fattori, T.R., Wilson, H.R., Harms, R.H. and Miles, D. (1991). Response of broiler breeder females to feed restriction below recommended levels. 1. Growth and reproductive performance. Poultry Science, 70:20 36.

Isikwenu, J.O. (2006). The Use of Urea treated and fermented brewer's dried grains in poultry diets. $\mathrm{PhD}$ Thesis, Department of Animal Science, Delta State University, Asaba Campus, Nigeria pp $4-6$.

Isikwenu, J.O. (2011). Performance and Economic Analysis of Cockerel chicks fed enzyme supplemented brewer's dried grains groundnut. Agriculture and Biology Journal of North America, Vol 2 (1): 47 - 51.

Isikwenu, J.O. and Omeje, S.I. (2007). The effects on the blood, carcass and organs of finisher broilers fed groundnut cake diets replaced with urea-treated and fermented brewer's dried grain. Agricultural Journal (Medwell Journals) 2 (1): $64-70$.

Isikwenu, J.O., Omeje, S.I., Okagbare, G. and Akpodiete, O.J. (2008). Effect of replacing groundnut cake with urea fermented brewer's dried grains in broiler chicks diets. Animal Research International, 5 (1): 795 - 800.

Lambert, W.V., Ellis, N.R., Block, W.H. and Titus, H.W. (1936). The role of nutrition in genetic research. The American Society of Animal Production 29:236 http://jas.fass.org/cgi/reprint/1936b/1/236-a

Mench, J.A. (2002). Broiler Feeders: Feed restriction and welfare. World's Poultry Science Journal, 58: 23 - 29.

Ojebiyi, O.O., Emiola, I.A., Rafiu, T.A., Hamzat, R.A. and Ademowo, I.O. (2009). Growth, haematological and serum biochemical response of broiler chickens fed graded levels of Kola (Cola acuminate) husk meal. Tropical Journal of Animal Science, 11: 110 - 120.

Seal, U.S. and Erickson, A.W. (1979). Haematology, blood chemistry and protein polymorphisms in the white tailed doer. Comp. Biochem. Physio, 39: 695.

SPSS 10.0 Statistical Package for the Social Sciences. SPSS/Inc. Chicago, IL, 60606.

Ubosi C.O (1998). Effects of quantitative feed restriction on productive performance and blood constituents of broiler pullets. pp 104 - 106. In: Ologhobo, A.D. and lyayi, E.A. (Eds). The Nigerian Livestock Industry in the $21^{\text {st }}$ Century. Proceedings of $3^{\text {rd }}$ Annual Conference of Animal Science Association of Nigeria. September $22^{\text {nd }}-24^{\text {th }} 1998$, Ikeja, Lagos.

Vipond, J.E., Lewis, M. and Allcroft, D.T. (2001) Urea preserved grains for finishing lambs. Proceedings of British Society of Animal Science pp 111 - 118 . 